\section{IgA vasculitis in adults: few certainties and many uncertainties}

We read with great interest the article on cardiovascular, thromboembolic and renal outcomes in patients with immunoglobulin A vasculitis (IgAV), published recently online in Annals of the Rheumatic Diseases. ${ }^{1}$

Tracy et al, estimated both a childhood and an adult onset of IgAV incidence rates and reported an increased risk of hypertension and chronic kidney disease in patients with IgAV, compared with age-matched and sex-matched controls based on retrospective data over a 12-year period extracted from a primary care database in the UK. They estimated the incidence rate of adult IgAV at 2.2 per 100 000 person-years, 1 which is close to the historic belief that IgAV rarely affects adults but was 2.3 times lower than the incidence rate of adult IgAV estimated at our secondary/tertiary medical centre in Slovenia at 5.1 (95\% CI 3.4 to 7.4) cases per 100000 persons per year. ${ }^{2}$ And we believed our estimation was rather conservative as we prospectively, over 3 years, included only histologically proven adult IgAV cases. Moreover, our patient cohort was considerably older (mean age 62.4 (18.8) vs. 43.3 (18.8) years) and suggested, in line with other epidemiological studies, ${ }^{3}$ a distinct male preponderance (63\% vs. $48.4 \%$ males), compared with the UK cohort of adult patients with IgAV. ${ }^{2}$ Although these differences may reflect the true differences between the two cohorts, they probably rather reflect the different methods of case ascertainment. Tracy et al, addressed some of the limitations and uncertainty regarding the classification of adult IgAV in their study. ${ }^{1}$ A French group demonstrated a very low positive predictive value of the D69.0 code of the 10th revision of the International Statistical Classification of Disease for an ascertainment of IgAV cases from electronic medical records. ${ }^{4}$

The current analysis of baseline clinical features and comorbidities of our prospective adult IgAV cohort over a 9-year period, consisting of 262 patients (median age (IQR) 64.6 (46.1-77.1) years, 59.5\% males, with kidney, gastrointestinal and articular involvement in $45.0 \%, 30.2 \%$ and $38.5 \%$, respectively) had a positive history of arterial hypertension, diabetes, hyperlipidaemia, ischaemic heart disease, stroke and chronic kidney disease in $48.9 \%, 19.9 \%, 19.1 \%, 5.0 \%, 3.4 \%$ and $17.9 \%$, respectively. Moreover, arterial hypertension and acute kidney injury were each diagnosed concurrently with IgAV in an additional $10 \%$ of patients. Our patients with IgAV more commonly had a history of arterial hypertension and diabetes mellitus than age matched controls in the Slovenian population in general (source: the National Institute of Public Health; ${ }^{5}$ Table 1). In addition, obesity was more prevalent in younger adults with IgAV than the age matched general Slovenian population. Regardless of, in our opinion, an over-conservative estimation of the incidence rate of IgAV, and an unexpected age and gender distribution in the reported UK cohort the associations of IgAV with hypertension, diabetes and obesity were noticed in both cohorts. It would be of a great interest to know whether these prevalent conditions contribute, if at all, to the risk of developing IgAV.

Hopefully, further studies of this oft-neglected, and contrary to common belief, not at all uncommon vasculitis in adults will improve our insight.

\section{Alojzija Hočevar, ${ }^{1,2}$ Matija Tomšič, ${ }^{1,2}$ Žiga Rotar ${ }^{1}$ \\ 'Department of Rheumatology, University Medical Centre Ljubljana, Ljubljana, Slovenia \\ ${ }^{2}$ Faculty of Medicine, University of Ljubljana, Ljubljana, Slovenia}

Correspondence to Dr Alojzija Hočevar, Department of Rheumatology, University Medical Centre Ljubljana, Ljubljana 1000, Slovenia; alojzija.hocevar@gmail.com

Handling editor Josef S Smolen

Contributors All authors meet the authorship requirements. AH contributed to the acquisition, analysis and interpretation of data. ZR and MT helped to revise the manuscript and gave suggestions. All authors have read and approved the manuscript for submission.

Competing interests None declared.

Patient consent Not required.

Provenance and peer review Not commissioned; internally peer reviewed. (c) Author(s) (or their employer(s)) 2020. No commercial re-use. See rights and permissions. Published by BMJ.

\section{Check for updates}

To cite Hočevar A, Tomšič M, Rotar Ž. Ann Rheum Dis 2020;79:e47.

Received 12 December 2018

Accepted 15 December 2018

Published Online First 5 January 2019

\section{Sinked}

http://dx.doi.org/10.1136/annrheumdis-2018-214951

Ann Rheum Dis 2020;79:e47. doi:10.1136/annrheumdis-2018-214907

\section{REFERENCES}

1 Tracy A, Subramanian A, Adderley NJ, et al. Cardiovascular, thromboembolic and renal outcomes in IgA vasculitis (Henoch-Schönlein purpura): a retrospective cohort study using routinely collected primary care data. Ann Rheum Dis 2019;78:261-9.

2 Hočevar A, Rotar Z, Ostrovršnik J, et al. Incidence of IgA vasculitis in the adult Slovenian population. Br J Dermatol 2014;171:524-7.

3 Piram M, Mahr A. Epidemiology of immunoglobulin A vasculitis (Henoch-Schönlein): current state of knowledge. Curr Opin Rheumatol 2013:25:171-8.

4 Deshayes $\mathrm{S}$, Moulis G, Pillebout E, et al. Positive predictive value of hospital discharge diagnosis code to identify immunoglobulin A vasculitis in France: a validation study. Eur J Intern Med 2017;43:e18-e19.

5 NIJZ. Podatkovni portal. 2017. Available: https://podatki.nijz.si/pxweb/sI/NIJZ\% 20podatkovni\%20portal

Table 1 The comparison between patients with IgAV and general population

\begin{tabular}{|c|c|c|c|c|c|c|c|c|c|c|c|c|c|c|}
\hline \multirow{2}{*}{$\begin{array}{l}\text { Age (years) } \\
\text { Characteristics }\end{array}$} & \multicolumn{2}{|c|}{$18-24$} & \multicolumn{2}{|c|}{$25-34$} & \multicolumn{2}{|c|}{$35-44$} & \multicolumn{2}{|c|}{$45-54$} & \multicolumn{2}{|c|}{$55-64$} & \multicolumn{2}{|c|}{$65-74$} & \multicolumn{2}{|l|}{$\geq 75$} \\
\hline & $\lg A V$ & Pop & $\lg A V$ & Pop & $\operatorname{Ig} A V$ & Pop & $\lg A V$ & Pop & $\operatorname{Ig} A V$ & Pop & $\lg A V$ & Pop & $\lg A V$ & Pop \\
\hline Hypertension (\%) & 0.0 & 3.5 & 0.0 & 3.6 & 7.7 & 10.4 & 25.8 & 22.5 & 53.5 & 39.2 & 71.7 & 50.7 & 77.5 & 59.9 \\
\hline Diabetes (\%) & 0.0 & 0.9 & 0.0 & 1.4 & 3.8 & 1.2 & 16.1 & 4.5 & 30.2 & 11.6 & 23.9 & 16.6 & 22.5 & 18.2 \\
\hline Ischaemic heart disease (\%) & 0.0 & 0.7 & 0.0 & 0.3 & 0.0 & 0.3 & 0.0 & 1.9 & 4.7 & 4.3 & 6.5 & 7.5 & 10.0 & 12.5 \\
\hline Stroke (\%) & 0.0 & 0.1 & 0.0 & 0.0 & 0.0 & 0.0 & 0.0 & 1.0 & 0.0 & 2.0 & 6.5 & 2.9 & 7.5 & 6.9 \\
\hline COPD $(\%)$ & 0.0 & 1.6 & 0.0 & 2.3 & 7.7 & 2.3 & 0.0 & 3.5 & 16.3 & 5.7 & 17.4 & 6.9 & 7.5 & 8.8 \\
\hline Current smokers (\%) & 23.1 & 24.0 & 21.7 & 33.2 & 30.8 & 29.7 & 32.3 & 31.2 & 27.9 & 24.3 & 19.6 & 9.4 & 3.8 & 4.1 \\
\hline BMI 25.0-29.9 (\%) & 38.5 & 18.4 & 47.8 & 30.4 & 23.1 & 40.1 & 19.4 & 37.4 & 14.0 & 41.9 & 26.1 & 42.7 & 28.8 & 43.4 \\
\hline $\mathrm{BMI} \geq 30(\%)$ & 15.4 & 5.1 & 0.0 & 8.1 & 38.5 & 16.2 & 48.4 & 24.3 & 44.2 & 28.8 & 32.6 & 25.9 & 31.3 & 20.8 \\
\hline
\end{tabular}

$\mathrm{BMI}$, body mass index $\left(\mathrm{kg} / \mathrm{m}^{2}\right)$; COPD, chronic obstructive lung disease; IgAV, immunoglobulin A vasculitis; Pop, population. 